Avi Gadoth, MD

Jaysingh Singh, MD

Jeffrey W. Britton, MD

Eoin P. Flanagan,

$\mathrm{MBBCh}$

Sean J. Pittock, MD

Neurol Neuroimmunol

Neuroinflamm

2017;4:e372; doi: 10.1212/

NXI.0000000000000372

\section{DACRYSTIC SEIZURES: A CRY FOR HELP OPEN}

A 69-year-old man with a history of myocardial infarction presented with crying-like spells. MRI demonstrated abnormal signal in the left mesiotemporal lobe, and he was diagnosed with stroke. Over the following 1 year, he developed progressive cognitive decline, slow gait, masked facies, hypophonic voice, and brief facial and upper extremity spasms (8 per hour) often followed by brief crying spells lacking emotion. Spell semiology was consistent with faciobrachial dystonic seizures $^{1}$ and dacrystic seizures ${ }^{2}$ (video at Neurology.org/nn). Leucine-rich glioma-inactivated-1 (LGI1) autoantibodies, detected in serum, led to a diagnosis of anti-LGI1 encephalitis. This is the first report of dacrystic seizures accompanying anti-LGI1 encephalitis.

From the Department of Laboratory Medicine and Pathology (A.G., E.P.F., S.J.P.) and Department of Neurology (A.G., J.S., J.W.B., E. P.F., S.J.P.), Mayo Clinic, Rochester, MN.

Author contributions: Avi Gadoth: data acquisition. Jaysingh Singh: data acquisition, EEG interpretation, and review of manuscript. Jeffrey W. Britton: EEG interpretation and review of manuscript. Eoin P. Flanagan: critical revision of
Clinical/Scientific Notes

manuscript. Sean J. Pittock: data acquisition and critical revision of manuscript.

Study funding: No targeted funding reported.

Disclosure: A. Gadoth and J. Singh report no disclosures. J.W. Britton received research support from Grifols and Mr. and Mrs. David Hawk charitable gift for epilepsy research. E.P. Flanagan reports no disclosures. S.J. Pittock and Mayo Clinic have a financial interest in patents that relate to functional AQPfINMO-IgG assays and NMO-IgG as a cancer market. S.J. Pittock consulted for Alexion and MedImmune and received research support from Grifols, MedImmune, and Alexion, RO1 NS-65829-91. Go to Neurology.org/nn for full disclosure forms. The Article Processing Charge was funded by the authors.

This is an open access article distributed under the terms of the Creative Commons Attribution-NonCommercial-NoDerivatives License 4.0 (CC BY-NC-ND), which permits downloading and sharing the work provided it is properly cited. The work cannot be changed in any way or used commercially without permission from the journal.

Received March 28, 2017. Accepted in final form April 23, 2017.

Correspondence to Dr. Gadoth: gadoth.a@mayo.edu

1. Irani SR, Michell AW, Lang B, et al. Faciobrachial dystonic seizures precede Lgi1 antibody limbic encephalitis. Ann Neurol 2011;69:892-900.

2. Blumberg J, Fernandez IS, Vendrame M, et al. Dacrystic seizures: demographic, semiologic, and etiologic insights from a multicenter study in long-term video-EEG monitoring units. Epilepsia 2012;53:1810-1819. 


\section{Neurology \\ Neuroimmunology \& Neuroinflammation}

Dacrystic seizures: A cry for help

Avi Gadoth, Jaysingh Singh, Jeffrey W. Britton, et al.

Neurol Neuroimmunol Neuroinflamm 2017;4;

DOI 10.1212/NXI.0000000000000372

This information is current as of June 16, 2017

\section{Updated Information \& Services}

Supplementary Material

References

Subspecialty Collections

Permissions \& Licensing

Reprints including high resolution figures, can be found at:

http://nn.neurology.org/content/4/4/e372.full.html

Supplementary material can be found at:

http://nn.neurology.org/content/suppl/2017/06/26/4.4.e372.DC1

This article cites 2 articles, 0 of which you can access for free at: http://nn.neurology.org/content/4/4/e372.full.html\#\#ref-list-1

This article, along with others on similar topics, appears in the following collection(s):

All Epilepsy/Seizures

http://nn.neurology.org//cgi/collection/all_epilepsy_seizures

Information about reproducing this article in parts (figures,tables) or in its entirety can be found online at:

http://nn.neurology.org/misc/about.xhtml\#permissions

Information about ordering reprints can be found online:

http://nn.neurology.org/misc/addir.xhtml\#reprintsus

Neurol Neuroimmunol Neuroinflamm is an official journal of the American Academy of Neurology.

Published since April 2014, it is an open-access, online-only, continuous publication journal. Copyright

Copyright (C) 2017 The Author(s). Published by Wolters Kluwer Health, Inc. on behalf of the American

Academy of Neurology.. All rights reserved. Online ISSN: 2332-7812.

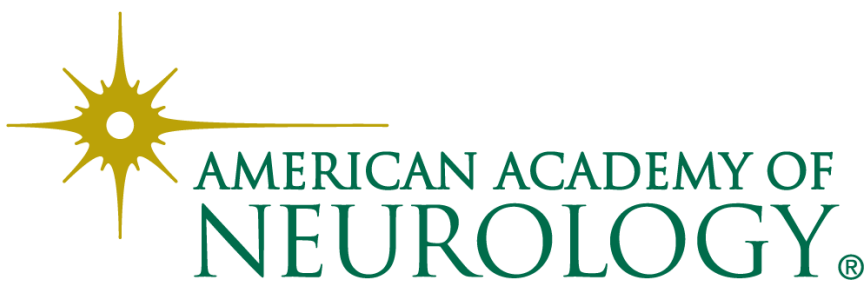

